Saudi Journal of Biomedical Research

Abbreviated Key Title: Saudi J Biomed Res ISSN 2518-3214 (Print) |ISSN 2518-3222 (Online)

\title{
Measurement of Serum Uric Acid Pre and Post Hemodialysis
}

Shaza Hassan Yahia*

Lecturer at Nahda College, Department of Clinical Chemistry, Medical Laboratory, Sudan

DOI: $\underline{10.36348 / \text { sjbr.2019.v04i12.005 }}$

| Received: 18.12.2019 | Accepted: 25.12.2019 | Published: 28.12.2019

*Corresponding author: Shaza Hassan Yahia

\section{Abstract}

This study was done to estimate the serum uric acid level pre and post dialysis. To do this 50 patients with chronic renal failure and 50 apparently health individual as control group were involved. Uric acid level was determined for all patients and control group and the result was analyzed using spss package. The mean of serum uric acid pre dialysis is significantly raised compare with that of the control group (9.4 \pm 2.2 versus $3.7 \pm 0.8)$. The mean of uric acid post dialysis is significantly decreased compared with that of before dialysis $(9.4 \pm 2.2$ versus $2.7 \pm 1.2)$ and P.value 0.00 . The sex frequency for pt with CRF (43.3\% female and 56.7\% male). The correlation between duration of disease and Serum uric acid significant negative correlation and the (P.value $=0.01 \mathrm{r}=-0.40)$.

Keywords: Serum Uric Acid, Post Hemodialysis, chronic renal failure.

Copyright @ 2019: This is an open-access article distributed under the terms of the Creative Commons Attribution license which permits unrestricted use, distribution, and reproduction in any medium for non-commercial use (NonCommercial, or CC-BY-NC) provided the original author and source are credited.

\section{INTRODUCTION}

Chronic kidney disease (CKD) is a type of kidney disease in which there is gradual loss of kidney function over a period of months to years. Initially there are generally no symptoms; later, symptoms may include leg swelling, feeling tired, vomiting, loss of appetite, and confusion [2]. Complications include an increased risk of heart disease, high blood pressure, bone disease, and anemia [1-6].

Causes of chronic kidney disease include diabetes, high blood pressure, glomerulonephritis, and polycystic kidney disease. Risk factors include a family history of chronic kidney disease. Diagnosis is by blood tests to measure the estimated glomerular filtration rate (eGFR), and a urine test to measure albumin [7-11].

\section{MATERIALS AND METHODS}

Study Design: Case control, Descriptive hospital base study.

Study Area and Period: Khartoum Hospital between February and March 2012.

\section{Inclusion Criteria and Exclusion}

- Inclusion criteria people whom have chronic renal failure
- Exclusion criteria people whom have gout, hypertension and DM.

\section{Sampling}

$2.5 \mathrm{ml}$ of venous blood collected in plain container immediately centrifuge to separate serum for investigation of uric acid or stored at -21c until used.

\section{METHOD}

Estimation of Uric Acid (Enzymatic Method)

Principle: (Uricase IPAP method)

Uricase converts uric acid to allantoin and hydrogen peroxide, the hydrogen peroxide formed further reacts with phenolic compound and 4-amino antipyrine by catalytic action of peroxidase to form a red colored quinoneimine dye complex.

Intensity of the color formed is directly proportional to the amount of uric acid present in the sample [8].

\section{RESULTS}

This study was carrying out in Khartoum hospital, on patients suffering from chronic renal failure.

Table-1: Age groups frequency

\begin{tabular}{|c|c|c|}
\hline Valid & Frequency & Percent \\
\hline $20 \_40$ & 19 & 63.3 \\
\hline $40 \_60$ & 11 & 36.7 \\
\hline Total & 30 & 100 \\
\hline
\end{tabular}


Table-2: Means, SD of serum uric acid in Sudanese pt with CRF

\begin{tabular}{|l|l|l|}
\hline Uric acid & Mean \pm SD $\mathbf{~ m g ~} \backslash \mathbf{d l}$ & P.value \\
\hline Pre dialysis & $9.4 \pm 2.2$ & 0.00 \\
\hline Post dialysis & $2.7 \pm 1.2$ & \\
\hline
\end{tabular}

Table-3: Mean of uric acid (mg/dl) in pt with renal failure before dialysis compare with control

\begin{tabular}{|l|l|l|l|}
\hline & \multicolumn{2}{|l|}{ Mean \pm SD } & P.value \\
\hline Uric acid $(\mathrm{mg} / \mathrm{dl})$ & Control & Pre dialysis & 0.00 \\
\cline { 2 - 3 } & $3.7 \pm 0.8$ & $9.4 \pm 2.2$ & \\
\hline
\end{tabular}

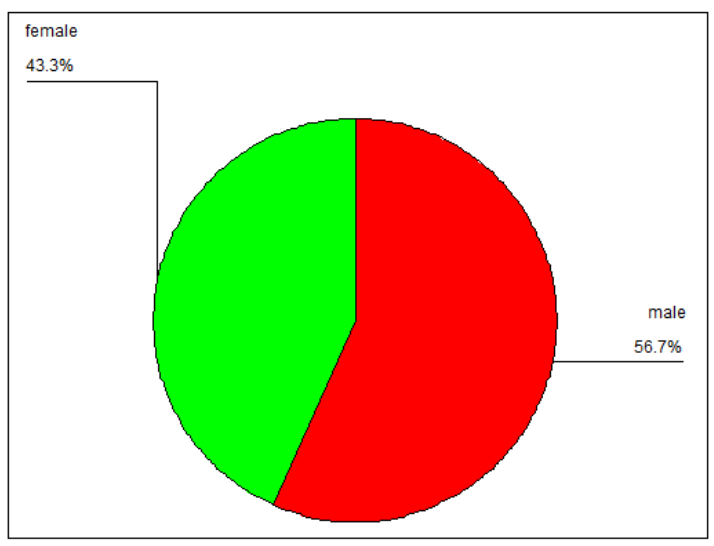

Fig-1: Sex frequency for pt with CRF

\section{Correlations}
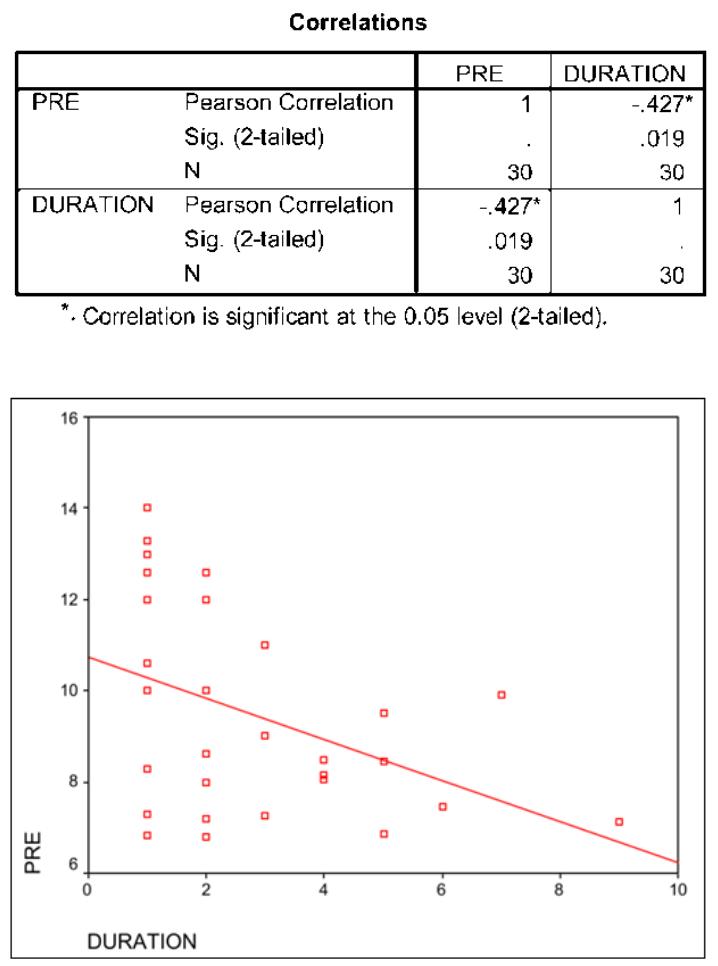

Fig-2: Scatter plot correlation between duration of disease and Serum uric acid significant negative correlation and the $P$.value $=0.01 r=-0.40$

\section{DISCUSSION}

This study was carry out in Khartoum hospital in Khartoum state (Sudan) try to though some light on renal failure patients by estimation of uric acid level in pre dialysis and post dialysis.

The result of this study showed significantly increased in the mean of uric acid level in patients compared with that of the control group Table 2 and 3

\section{CONCLUSION}

Uric acid level elevated in all renal failure patients ,but its level return to normal range after dialysis ,so that dialysis was to return some of the parameter change (like uric acid) in patient with renal failure to the normal range.

\section{REFERENCES}

1. Ridge, B. B. (2006). Human physiology, higher Education, Boston Burr Ridge, 11 Dubuque, 1A Madison ninth edition, 551-552.

2. Jacob, S. T. (2002). Atlas of human anatomy Churchill ST Louis Sydney Toronto sixth edition, 128-134.

3. Bishop, M. L., Fody, E., \& Pand, S. L. (1985). Eclinical chemistry techniqunies principles, correlations wolters kluwery, sixth edition Lippincott and Wilkins, 556-560.

4. Mayn, Z. P. (1994). Clinical chemistry in Diagnosis and treatment Arnold, London. Sydney Auckland co-published in the USA by oxford university press, Inc, newyork fifth edition, 2-4.

5. Tietz, N. W. (1987). Fundamentals of clinical chemistry third edition W.B.saunders Company, 684-686.

6. Marshall, W. J., \& Bangert, S. K. (2004). Clinical chemistry Mosby Edinburgh London New York oxford philaderhia ST Louis Sydney Toronto fifth edition, 184-287.

7. Bishop, M. L., Engel, K. J., \& Land-Fody, E. P. (2000). Clinical chemistry principles, correlations fifth edition Lippincott Williams and Wilkins, 444.

8. Mayn, Z. P. Clinical chemistry in Diagnosis and treatment Arnold, London. Sydney Auckland copublished in the USA by oxford university press, Inc, New York sixth edition; 173-183.

9. Arthur C., \& Gwyton, M. D. (2000). Text book of medical physiology. $9^{\text {th }}$ edition .USA, 420.

10. Ramink, S. (2006). Text book of medical laboratory technology, Jaypee brothers, 649.

11. Shingo, S. K., Tarkurou, F. K., \& Anzawa, M. Y. (2010). Division of cariology department of internal Medicine, 270-277. 